\title{
AGAINST WOLTERSTORFF'S THEISTIC ATTEMPT TO GROUND HUMAN RIGHTS
}

\author{
David Redmond
}

$N^{i n}$ ICHOLAS WOLTERSTORFF is concerned to find an appropriate grounding of human rights understood as inherent natural rights. Unforturights is available. Fortunately, however, he thinks that an adequate theistic account of the grounds of human rights is available. According to his proposed account, human rights are grounded in our standing in the relation of being loved by God. ${ }^{1}$ After saying a word about how Wolterstorff understands rights in general and human rights in particular, I explain his proposed theistic account of the grounding of human rights and argue that it fails.

\section{WOLTERSTORFF ON THE PROJECT OF GROUNDING HUMAN RIGHTS}

For Wolterstorff, rights are a particular kind of normative social relationship. In particular, they are legitimate claims against another to the good of being treated in a way befitting of the right-holder's worth. ${ }^{2}$ In order to possess a right, one must have a certain status. For example, to have the right to an NBA championship ring, one must have the status of having been a member of a team that won the NBA finals. A human right is a right such that the status sufficient for possessing the right is the status of being a human being. ${ }^{3}$ That is, Wolterstorff assumes

1 See Wolterstorff, "Can Human Rights Survive Secularization." For a more complete explication of his argument, see Wolterstorff, Justice: Rights and Wrongs. He offers a revised account in Justice in Love, ch. 14. He offers yet another revision of the argument in "On Secular and Theistic Groundings of Human Rights." For his most recent defense, see "Why Naturalism Cannot Account for Natural Human Rights." Christopher J. Eberle offers a similar argument in "Basic Human Worth: Religious and Secular Perspectives."

2 For his detailed account of the nature of rights, see Justice: Rights and Wrongs, especially 241-310.

3 It is worth noting that Wolterstorff thinks of human rights — and, indeed, all rights—as prima facie rights. Even with this qualification, he thinks the common explanation is still not technically correct because he holds both that rights imply corresponding duties and that 
what Tasioulas calls the "orthodox view": human rights are moral rights that one has simply in virtue of being a human being. ${ }^{4}$ Many other contemporary writers agree with this characterization of human rights as natural rights. Griffin, for example, claims that human rights just are natural rights by a different name. $\mathrm{He}$ writes, "The French marked the secularization of the concept by changing its name from 'natural rights' to 'human rights' ... The secularized notion that we were left with at the end of the Enlightenment is still our notion today. Its intension has not changed since then: a right that we have simply in virtue of being human."

Wolterstorff recognizes that one can attempt to come to understand the nature of human rights either by starting from a standard list (like the UDHR) or by starting with the common explanation of human rights. The above makes it clear that, at least for present purposes, Wolterstorff has opted for the latter option. Those who favor the alternative starting place might worry that Wolterstorff does not correctly understand the nature of human rights. ${ }^{6}$ And even those who are happy to begin with the common explanation of human rights might still suggest that the orthodox view must be qualified in some way or another. ${ }^{7}$ For present purposes, such debates can be set aside. What is significant is that Wolterstorff takes as his starting point a widely accepted definition of human rights and claims that a secular grounding of human rights, so understood, is not available.

Though his exploration of human rights does not begin with the UDHR, he does agree with the UDHR in thinking that human rights are grounded in some dignity or worth that humans possess. ${ }^{8}$ But as Wolterstorff points out, dignity "does not just settle on things willy-nilly." There must be some feature about

there might arise circumstances in which no one has the relevant duty because no one is in a position to bestow the relevant good on the alleged right holder. In such a case, one's right is blocked. See "On Secular and Theistic Groundings of Human Rights," 179-81.

4 Tasioulas, "On the Foundations of Human Rights," 45.

5 Griffin, "On Human Rights," 1-2.

6 For an overview of the debate between naturalists and political conceptions of human rights, see Cruft, Liao, and Renzo, "The Philosophical Foundations of Human Rights: An Overview," 4-10.

7 See, for example, Griffin's explication of the term "human" in "human rights" in his "On Human Rights," 34-35. Cf. Simmons, "Human Rights, Natural Rights, and Human Dignity," 145. Wolterstorff admits that the writers of the UDHR seem not to be interested in human rights as he understands them; instead, they are concerned with what he calls "full-fledged human person rights," i.e., rights one has merely in virtue of being a full-fledged human person. See his "Grounding the Rights We Have as Human Persons," 203-4.

8 See his Justice: Rights and Wrongs, ch. 13, for a defense of a dignity-based grounding of rights.

9 Wolterstorff, “On Secular and Theistic Groundings of Human Rights," 182. 
us on which the dignity supervenes. Identifying such a feature is the project of grounding human rights. The relevant feature must meet the following conditions: first, it is a feature that all human beings must have-a feature that no human can lack while remaining human. The reason for this is as follows: the status of being a human being is sufficient for possessing human rights. So, if human rights are grounded in dignity, then both the dignity that grounds human rights and the feature on which it supervenes must be inseparable from the status of being a human being. Second, because the entire package of human rights is unique to humans, the feature on which the dignity that grounds human rights supervenes must likewise be a uniquely human feature. And third, Wolterstorff and many others come to the table with the intuition that all humans have some dignity or worth in virtue of which they are due respect such that certain ways of treating them are unacceptable. The feature we're seeking must explain this; it must illuminate our intuition that all humans-even the significantly cognitively impaired-have a worth that explains why certain ways of treating them are unacceptable. Wolterstorff's contention is that there is no such feature (or combination of features) readily available to the secularist. He considers various secular accounts that attempt to ground human rights in the capacity for either rational agency or personhood. Unfortunately, such accounts clearly fail the first condition; not all humans have the relevant capacities. Furthermore, not only do some humans not currently possess such capacities, some humans never did and never will possess such capacities. Wolterstorff also considers a secular view according to which human rights are ultimately grounded in human nature. He argues, however, that while such a feature clearly meets the first two conditions, it fails to meet the third condition; possessing a human nature does nothing to illuminate our intuition that the significantly cognitively impaired have a worth that explains why certain ways of treating them are unacceptable. For purposes of this essay, I set aside whether Wolterstorff succeeds in defeating the above-mentioned secular accounts. ${ }^{10}$ Instead, I focus on his proposed theistic grounding of human rights. In the remaining section, I explain his theistic account and argue that it fails.

2. WOLTERSTORFF'S THEISTIC ACCOUNT

OF THE GROUNDING OF HUMAN RIGHTS

Perhaps the standard theistic account of the grounding of human rights appeals to the biblical notion of the imago dei. According to this account, humans have

10 Indeed, Wolterstorff would be pleased to discover that he has not. See his "Can Human Rights Survive Secularization," 420. 
worth because they are made in the image of God. Of course, to evaluate such an account, we must first know how to understand the notion of the imago dei. Unfortunately, theologians have tended to understand it either directly in terms of the capacity for rational agency or personhood or else in terms that clearly imply those capacities. ${ }^{11}$ If this is correct, then, if Wolterstorff's critique of secular accounts is successful, the theist cannot ground human rights in the imago dei because, once again, not all humans have the relevant capacities. Wolterstorff, therefore, offers an alternative theistic account according to which human rights are grounded in a particular relationship in which we stand to God-namely, the relation of being loved by God in such a way that worth is bestowed on us.

Not all species of love bestow worth, however. ${ }^{12}$ For instance, one loves with "love as attraction" when the lover is attracted to the object of love in virtue of some aspect or worth of the object of love. "The love gives rise to desire for engagement with the things loved; the lover anticipates that his well-being will be enhanced by that engagement." 13 This sort of love will not do the work that Wolterstorff desires because it does not enhance or bestow worth; rather, it recognizes worth that is already present. By contrast, love as benevolence-at least when successful-does enhance worth, but "the enhancement does not consist simply in the person's being an object of benevolence; it consists in some alteration in his or her life that the lover causes." ${ }^{14}$ For example, a man's life would go better if one provides him with food, but his receiving the food would have made his life better even if it was not motivated by benevolence.

In his original version of the argument, Wolterstorff argues that human rights are grounded in a third species of love, what he calls "love as attachment." He illustrates with a story of a boy named Nathan who loves his ugly stuffed animal. ${ }^{15}$ Nathan even recognizes that it is ugly and that many other stuffed animals are nicer in various respects. Nevertheless, Nathan loves his stuffed animal. It is the one with which he has bonded; it is the one to which he is attached. This theistic account of the grounding of human rights was subject to extensive criticism, ${ }^{16}$ and Wolterstorff no longer thinks that love as attachment can do the work he ascribed to it. He now concedes that God's loving all humans with love as attach-

Wolterstorff, "On Secular and Theistic Groundings of Human Rights," 194.

Wolterstorff distinguishes a variety of species of love in his Justice: Rights and Wrongs, 358-60.

Wolterstorff, Justice: Rights and Wrongs, 358-59.

Wolterstorff, Justice: Rights and Wrongs, 359.

Wolterstorff, Justice: Rights and Wrongs, 359.

See, for example, Bernstein, "Does He Pull It Off? A Theistic Grounding of Natural Inherent Human Rights?”; Weithman, “God's Velveteen Rabbit”; and Murphy, review of Justice: Rights and Wrongs. 
ment merely gives transitive moral significance to each human. It explains why harming a human being may be a way of wronging God, but it does not explain why harming a human being is a way of wronging the human being. ${ }^{17}$

In his most recent treatments of the topic, Wolterstorff argues that there is yet another kind of love that can do the trick. He calls it "love as the desire for friendship." ${ }^{18} \mathrm{He}$ invites us to imagine a good and beloved monarch who, because he is lonely, decides to befriend a few of his subjects. Those chosen are honored to be chosen as his friends. They "will cite that fact under 'Honors' in their curricula vitae. ${ }^{19}$ He continues:

Now for the crucial point. To be honored is to have worth bestowed on one. Admittedly, this is somewhat mysterious. But an indication of the fact that this is what happens is that to be honored is to acquire new grounds for respect and, hence, new ways in which one can be demeaned and wronged; and that's possible only if there has been some alteration in one's worth. The most obvious way in which one can now be demeaned and wronged is by having the honor itself belittled. One who has not been chosen by the monarch for friendship sarcastically remarks to someone who has been chosen, "Big deal!” The latter has a right to be angry; this is a snub. Depending on the situation, the snub may count as a snubbing of the one who bestowed the honor; but in any case, it amounts to snubbing the one honored. Honoring bestows worth. ${ }^{20}$

The relevant analogy is obvious. A theist might plausibly maintain that God desires friendship with all human beings. Indeed, many Christians believe that the metanarrative of all history involves God's pursuit of a restored relationship with each of the humans he created. Such a desire for human friendship constitutes a way in which God honors us, and being honored by God in this way is to have worth bestowed on us. Furthermore, God's desire for friendship with human beings rather than, say, crocodiles is not arbitrary because, unlike crocodiles, we have the potential for friendship with God because it is in our nature to be persons.

Jordan Wessling has recently argued that Wolterstorff's account is subject to something similar to the traditional Euthyphro dilemma. ${ }^{21}$ If he is right, then we

Wolterstorff, “On Secular and Theistic Groundings of Human Rights," 196-97.

See Wolterstorff, "On Secular and Theistic Groundings of Human Rights," 197-200, and "Why Naturalism Cannot Account for Natural Human Rights," 259-61.

Wolterstorff, “On Secular and Theistic Groundings of Human Rights,” 198.

Wolterstorff, “On Secular and Theistic Groundings of Human Rights,” 198.

Wessling, "A Dilemma for Wolterstorff's Theistic Grounding of Human Dignity and Rights." 
have a rebutting defeater for Wolterstorff's account. But regardless of whether Wessling is right, Wolterstorff's argument is subject to an undercutting defeater. As he presents the argument, it depends on two claims: (1) The monarch's desiring friendship with his subjects is a way of honoring them, and (2) Honoring his subjects in this way bestows worth. Suppose we grant to Wolterstorff the first claim. ${ }^{22}$ Still, the crucial point concerns whether we have any reason to think that being honored in this way bestows worth. Wolterstorff admits that this is mysterious. I agree, and I think I can explain the mystery: his argument that honoring bestows worth is spurious.

Wolterstorff claims that those subjects with whom the monarch desires to be friends has acquired new ways in which he or she can be demeaned and wronged. Call one such subject, "James." He writes, "The most obvious way in which [James] can now be demeaned and wronged is by having the honor itself belittled. One who has not been chosen by the monarch for friendship sarcastically remarks to [James], 'Big deal!' ... This is a snub." ${ }^{23}$ We should ask two questions about James: (1) Does James acquire new ways in which he can be wronged in virtue of the monarch's desire for friendship? (2) If so, does this indicate that the monarch's desire bestowed worth on James? The success of Wolterstorff's arguments depends on his defense of an affirmative answer to both questions. Unfortunately, his defense fails. To begin with, it is not clear that James does acquire new ways of being wronged. ${ }^{24}$ To see this, imagine that the monarch does not, in fact, desire friendship with James, but both James and his acquaintance falsely believe that he does. In this case, it seems that James would be wronged in precisely the same way if his acquaintance exclaimed, "Big Deal!" This suggests that James does not acquire new ways of being wronged in the case that Wolterstorff imagines.

But suppose I am wrong about that. Suppose James does acquire new ways in which he can be wronged. In this case, however, James's acquiring new ways in which he can be wronged is not indicative of new worth. To see this, return to the original case in which the monarch really does desire friendship with James, and his acquaintance sarcastically responds, "Big deal!” It is plausible that such a response constitutes wronging James insofar as it is disrespectful to show

Because I am not sure what exactly is involved in honoring someone, I am unsure whether the monarch's desiring friendship with some individual, $X$, constitutes honoring $X$. In any case, the premise is superfluous. Wolterstorff's argument succeeds if he can establish both that God's desire for friendship with humans generates new ways in which they can be demeaned and wronged and that the generation of such ways is indicative of new worth. Wolterstorff, “On Secular and Theistic Groundings of Human Rights,” 198.

24 This depends, in part, on how one individuates ways of being wronged. 
contempt for his experiencing some good in his life. We need not think that it is due to some new worth that was bestowed on him. ${ }^{25}$ Modify the case once again. Imagine, instead, that James has won a new car and is excited about his vehicle. He would be wronged if his acquaintance responded, "Big deal!" The explanation I suspect is the same in both cases; in neither case do we need to suppose that James is wronged because of some new worth that he acquired. Rather, James is wronged because someone showed disrespect for a person (who already possesses worth) by showing contempt for the acquisition of some good in his life. So, even if we grant that James acquires a new way in which he can be wronged when the monarch comes to desire friendship with him, this does not imply that he has undergone an alteration in worth. One can acquire new ways of being wronged just in virtue of acquiring new goods in one's life. If that is correct, then Wolterstorff fails to adequately defend his theistic account of the grounding of human rights. While he may have located a feature that - given some plausible theistic assumptions - meets his first and second conditions, he provides no reason to suppose it meets the third. His attempt to argue that it does is spurious because not only is it unclear whether God's desire for friendship with humans generates new ways in which they can be wronged, but even granting that it does, acquiring new ways in which one can be wronged does not indicate that worth has been bestowed. Without justification for thinking that worth has been bestowed, Wolterstorff provides no justification for thinking that the theist succeeds where the secularist—at least in Wolterstorff's estimationfails. If all humans have a dignity or worth in virtue of which they have certain rights, then, if Wolterstorff's criticisms of the secular accounts are cogent, a dignity-based grounding of those rights remains elusive. ${ }^{26}$

\author{
University of Iowa \\ david-redmond@uiowa.edu
}

25 Wolterstorff recognizes that, because a human is a substance and his or her life is an event, a human being is not identical with his or her life. He also explicitly notes that, "from the fact that the state of affairs of my being $K$ is a good in my life, it does not follow that my having the property of being $K$ makes a positive contribution to my worth as a human being." See Justice: Rights and Wrongs, 142-43. It seems to me that Wolterstorff's revised theistic grounding of human rights neglects this important fact.

Many thanks to the members of the University of Iowa Graduate Philosophical Society as well as the participants at the 2016 Midsouth Philosophy Conference, the 2016 Midwest meeting of the Society of Christian Philosophers, and the 2017 Jakobsen Memorial Conference for discussions on earlier drafts. 
Bernstein, Richard J. "Does He Pull It Off? A Theistic Grounding of Natural Inherent Human Rights?" Journal of Religious Ethics 37, no. 2 (June 2009): 221-42.

Cruft, Rowan, S. Matthew Liao, and Massimo Renzo, eds. Philosophical Foundations of Human Rights. Oxford: Oxford University Press, 2015.

- "The Philosophical Foundations of Human Rights: An Overview." In Cruft, Liao, and Renzo, Philosophical Foundations of Human Rights, 1-44.

Eberle, Christopher J. "Basic Human Worth: Religious and Secular Perspectives." In New Waves in Philosophy of Religion, edited by Yujin Nagasawa and Erik J. Wielenberg, 167-91. New York: Palgrave Macmillan, 2009.

Griffin, James. On Human Rights. Oxford: Oxford University Press, 2008.

Murphy, Mark. Review of Justice: Rights and Wrongs, by Nicholas Wolterstorff. Ethics 119, no. 2 (2009): 402-7.

Simmons, A. John. "Human Rights, Natural Rights, and Human Dignity." In Cruft, Liao, and Renzo, Philosophical Foundations of Human Rights, 138-52.

Tasioulas, John. "On the Foundations of Human Rights." In Cruft, Liao, and Renzo, Philosophical Foundations of Human Rights, 45-70.

Weithman, Paul. “God's Velveteen Rabbit." Journal of Religious Ethics 37, no. 2 (June 2009): 243-60.

Wessling, Jordan. "A Dilemma for Wolterstorff's Theistic Grounding of Human Dignity and Rights." International Journal for Philosophy of Religion 76, no. 3 (December 2014): 277-95.

Wolterstorff, Nicholas. "Can Human Rights Survive Secularization." Villanova Law Review 54, no. 3 (2009): 411-20.

. "Grounding the Rights We Have as Human Persons." In Understanding Liberal Democracy: Essays in Political Philosophy, 201-26.

- Justice in Love. Grand Rapids, MI: Eerdmans, 2011.

- Justice: Rights and Wrongs. Princeton, NJ: Princeton University Press, 2008.

. "On Secular and Theistic Groundings of Human Rights." In Understanding Liberal Democracy: Essays in Political Philosophy, 177-200.

- Understanding Liberal Democracy: Essays in Political Philosophy. Edited by Terence Cuneo. Oxford: Oxford University Press, 2012

- "Why Naturalism Cannot Account for Natural Human Rights." In The Blackwell Companion to Naturalism, edited by Kelly James Clark, 447-61. Malden, MA: Wiley-Blackwell, 2016. 